\title{
PERAN MEDIA CERITA DALAM MENGEMBANGKAN \\ KEMAMPUAN BERBICARA PADA ANAK MELALUI KEGIATAN SHOW AND TELL
}

\author{
Laras Pangestuti, S.Pd \\ PAUD FIP Universitas Negeri Yogyakarta \\ Email: laraspangestuti20@gmail.com
}

\begin{abstract}
Abstrak
Penelitian ini bertujuan untuk mengetahui pengaruh media cerita berupa foto dan gambar hasil karya anak terhadap kemampuan berbicara anak usia dini di TK ABA Pantisiwi Bantul. Penelitian ini merupakan penelitian eksperimen dengan desain quasi eksperimen.Subjek penelitian ini adalah anak kelompok A TK ABA Pantisiwi Bantul yang berjumlah 40 anak.Obyek penelitian ini adalah kemampuan berbicara.Teknik pengumpulan data dengan menggunakan metode observasi dan tes.Instrumen yang digunakan adalah dengan lembar observasi. Teknis analisis data yang digunakan adalah dengan menghitung mean pre-test dan mean post-test kelompok kontrol dan kelompok eksperimen. Dari hasil penelitian menunjukkan bahwa peran media cerita berupa foto mampu mengembangkan kemampuan berbicara anak sebesar 70,61\%, sedangkan media gambar dari hasil karya anak mampu mengembangkan kemampuan berbicara sebesar 55,3\%.
\end{abstract}

Kata kunci: media, foto, hasil karya, kemampuan berbicara.

\begin{abstract}
Aim of the research is to define the influence of story media in the form of photographs and student drawings to the speaking skill of early-aged children in TK ABA Pantisiwi Bantul. The study is categorized into an experiment research using quasi experiment design. Subject of the research were 40 students of group $A$ in TK ABA Pantisiwi Bantul. Object of the research was the students' speaking skill. Data was collected using observation and test methods. Instrument used was in the form of observation field note. Data was then analyzed by calculating mean of pre-test and mean of post test of the control group and experiment group. The research result showed that the role of the story media in the form of photographs were able to improve the students' speaking skill into $70.61 \%$ while the student drawings were able to improve the students' speaking skill into 55.3\%.
\end{abstract}

Keywords: media, photograph, work of art, speaking skill

PENDAHULUAN

Bahasa merupakan hal yang penting bagi manusia untuk berkomunikasi dengan masyarakat sosial disekitarnya.Bahasa menurut Webster (Sardjono, 2005: 5) adalah komunikasi atau ekspresi fikir dan perasaan yang berwujud vokal dan merupakan kombinasi dari beberapa bunyi atau simbol-simbol tertulis yang mengandung arti.Sependapat dengan Webster, Santrock (2007: 353) menjelaskan bahwa bahasa adalah suatu bentuk komunikasi, baik itu lisan, tertulis atau isyarat yang berdasarkan pada suatu sistem dari simbol-simbol.Sehingga melalui bahasa anak dapat menjalin komunikasi dengan oranglain dan lingkungannya.

Pada masa kanak-kanak awal perkembangan bahasa yang pesat 
dipengaruhi oleh perkembangan kognitif.Santrock (2007: 205) menjelaskan bahwa bahasa berhubungan juga dengan sosial dan kognitif. Menurut Santrock "social cognition refers how individuals conceptualize and reason about their social world - the people they watch and interact with, relationships with those people, the groups in which the participate, and how they reason about themselves and others." Inti dari pernyataan tersebut adalah bagaimana seseorang berinteraksi dengan orang lain, memiliki konsep individu, hubungan dengan orang disekitar dan bagaimana mereka berpikir mengenai dirinya sendiri dan orang lain.Pada masa ini anak telah masuk pada fase prakonseptual yaitu dimana anak telah mampu membedakan nama-nama benda disekitarnya dan melihat hubungan fungsional antara bendabenda yang telah anak ketahui namanya.

Menurut Bygate (1987:26) bahwa dalam berbicara seseorang harus mempunyai pengetahuan keterampilan perspektif motorik, dan keterampilan interaktif, maka agar dapat bercerita dengan baik, seseorang harus mempunyai kompetensi kebahasaan yang memadai serta unsur-unsur yang menjadi syarat agar proses berbicaranya dapat lancar, baik dan benar. Diantaranya adalah lafal, intonasi, ejaan, kosa kata, dan sebagainya.

Kemampuan berbicara sangat penting untuk anak karena dengan berbicara anak dapat mengkomunikasikan tentang keadaan dirinya.Misalnya, kasus anak yang kehilangan orangtuanya di pusat perbelanjaan. Hal ini dikarenakan anak sulit untuk berkomunikasi dengan oranglain, menyampaikan maksud dan menjelaskan keadaan dirinya dengan oranglain. Kasus hilangnya anak di pusat perbelanjaan ini merupakan salah satu bukti bahwa kemampuan berbicara adalah hal yang penting. Dijelaskan pada website the asian parent bahwa pada umumnya ketika anak hilang di tempat umum, orangorang sekitar akan memberi pertanyaan sederhana kepada anak tersebut.
Pertanyaan yang mungkin biasa ditanyakan adalah "siapa mama-nya?". Dengan demikian mengajarkan dan memberikan stimulus untuk kemampuan berbicara anak merupakan hal yang penting dilakukan.

Kasus lain terkait kemampuan berbicara pada anak yaitu terjadi pada anak awal masuk sekolah. Pada saat awal masuk sekolah anak sangat sulit berkomunikasi dan mengutarakan keinginannya baik dengan temannya, orang lain atau pada saat anak bercerita di depan kelas. Kejadian tersebut dapat dikarenakan belum adanya rasa keberanian anak serta minimnya motivasi dari seorang guru untuk mengungkapkan dan mengutarakan keinginannya lewat bahasa lisan. 85\% anak pada saat awal masuk sekolah malu untuk mengutarakan maksud serta berbicara dan menjelaskan maksud dengan teman dan oranglain. Selain itu masih kurangnya kosa kata yang dimiliki anak serta rasa percaya diri anak untuk mengutarakan dan menyampaikan maksud menjadi faktor kendala.

Selain faktor dalam diri anak, metode mengajar guru dan media pembelajaran juga sangat mempengaruhi kemampuan berbicara anak. Penerapan metode dan penggunaan media yang tepat dalam kegiatan belajar mengajar, diharapkan akan mampu meningkatkan daya keaktifan anak dalam pembelajaran. Melihat faktor tersebut, maka dengan pemanfaatan metode dan media yang tepat anak akan dapat mengembangkan pengetahuan, sikap dan keterampilan sehingga dapat berkembang dengan baik. Namun, pada umumnya pembelajaran keterampilan berbicara di Taman kanakkanak kurang maksimal, guru cenderung lebih dominan pada pembelajaran seharihari dan media yang digunakan kurang bervariatif. Kurang kreatif penggunaan media tersebut membuat keterampilan berbicara belum tercapai secara optimal.Terbukti anak masih takut untuk mengemukakan pendapat, malu bertanya, kurang percaya diri dalam berkomunikasi, 
sulit untuk mengungkapkan kembali isi cerita dan sebagainya. Maka dari itu peran media cerita sangatlah penting untuk mengembangkan kemampuan berbicara.

$$
\text { Dalam mengembangkan }
$$

kemampuan berbicara anak, pendidik dapat menggunakan berbagai media. Media berasal dari bahasa latin medium (antara), istilah tersebut merujuk pada apa saja yang membawa informasi antara sebuah sumber dan sebuah penerima (Sharon, Deborah dan James 2011: 7). Berdasarkan pendapat tersebut, dapat dikatakan media sebagai perantara atau apapun yang memberikan informasi bagi penerima informasi.Media yang digunakan dalam mengembangkan kemampuan berbicara beragam, dapat menggunakan media dua dimensi atau tiga dimensi.Salah satu media dua dimensi yang dapat mengembangkan kemampuan berbicara anak adalah gambar dan foto.Penggunaan gambar cerita merupakan alat bantu (media) agar menstimulasi anak untuk mengembangkan kemampuan berbicaranya. Dengan media ini diharapkan anak terangsang untuk menyampaikan maksud, ide, gasan dan pendapatnya.

\section{METODE PENELITIAN}

Penelitian ini menggunakan pendekatan kuantitatif.Pendekatan kuantitatif Menurut Nana Syaodih Sukmadinata (2010: 53) menjelaskan bahwa pendekatan kuantitatif adalah jenis pendekatan yang dilakukan dengan menggunakan angka-angka, pengolahan statistik, struktur dan percobaan kontrol.

\section{Jenis Penelitian}

Jenis penelitian yang digunakan dalam penelitian ini adalah eksperimen. Menurut Suharsimi Arikunto (2006: 3) mengemukakan eksperimen adalah suatu cara untuk mencari hubungan sebab akibat (hubungan kausal) antara dua faktor yang sengaja ditimbulkan oleh peneliti dengan mengeliminasi atau mengurangi atau menyisihkan faktor-faktor lain yang dapat mengganggu. Dengan kata lain penelitian eksperimen mencoba meneliti ada atau tidaknya hubungan suatu sebab akibat.

\section{Waktu dan Tempat Penelitian}

Penelitian ini dilakukan pada bulan Mei 2016.Penelitian ini dilaksanakan di TK ABA Pantisiwi Serut Bantul, yang terletak di Serut, Peni, Palbapang, Bantul, Yogyakarta.

\section{Target/Subjek Penelitian}

Subjek dalam penelitian ini adalah peserta didik kelompok A di TK ABA Pantisiwi Serut pada Tahun Ajaran 2015/2016. Jumlah siswa kelompok A adalah 40 anak yang merupakan kelompok A1 sebagai kelompok kontrol yang berjumlah 21 anak dan kelompok A2 sebagai kelompok eksperimen yang berjumlah 19 anak.

\section{Data, Instrumen, dan Teknik Pengumpulan Data}

Jenis data penelitian ini adalah kualitatif adalah data nominal tentang kemampuan berbicara kelompok kontrol dan kelompok eksperimen yang muncul selama proses penelitian.

Teknik pengumpulan data yang digunakan pada penelitian ini adalah dengan pedoman lembar observasi menggunakan pedoman intrumen 12 butir berbentuk checklist yang dilakukan pada saat pre-test dan post-test kedua kelompok dengan bantuan dari tester dalam menjawabnya. Kemampuan berbicara yang diukur dalam penelitian ini meliputi kemampuan menyampaikan maksud (ide, pikiran, gagasan dan perasaan) dalam bentuk kata/bahasa dengan artikulasi yang jelas dan kemampuan memberi jawaban dan tanggapan dengan pilihan kata dan kalimat yang tepat. Indikator kemampuan berbicara yang digunakan pedoman dalam instrumen pada penelitian ini adalah : 1) kemampuan menyampaikan ide/gagasan; 2) kemampuan menyampaikan isi perasaan; 3) kemampuan menceritakan 
kembali; 4) kemampuan memberi salam; 5) kemampuan menjawab salam; 6) kemampuan menjawab pertanyaan dan 7) kemampuan mengajukan pertanyaan.

\section{HASIL PENELITIAN DAN PEMBAHASAN}

Berdasarkan hasil penelitian
dinyatakan bahwa ada pengaruh
penggunaan media cerita berupa gambar hasil karya anak dan foto terhadap kemampuan berbicara anak kelompok A TK ABA Pantisiwi Serut Bantul semester II pada tahun ajaran 2015-2016. Pendapat dari Hurlock (1978: 186) terbukti benar, bahwa dorongan atau motivasi dari dalam diri ataupun dari luar anak mempengaruhi kemampuan berbicara. Semakin banyak anak didorong untuk berbicara dengan mengajaknya berbicara dan didorong untuk menanggapinya, maka akan semakin baik kualitas bicaranya. Dan dengan media yang digunakan maka anak akan termotivasi serta terdorong untuk berbicara dan menjelaskan tentang benda tersebut. Dengan anak diajak untuk bicara dan didorong guru untuk menjelaskan serta menanggapi benda yang ia bawa, anak akan terstimulasi dan kemampuan berbicara anak meningkat.Pada penelitian ini peran media foto dalam mengembangkan kemampuan berbicara lebih tinggi dibandingkan dengan media hasil karya anak.Berikut adalah presentase hasil penelitian pada kelas eksperimen dengan penggunaan media foto dan hasil karya anak untuk mengembangkan kemampuan berbicara.

Tabel 1. Presentase Hasil Penelitian Pada Kelas Eksperimen

\begin{tabular}{|c|c|}
\hline Media & $\begin{array}{c}\text { Presentase } \\
\text { Kemampuan Berbicara }\end{array}$ \\
\hline Foto rekreasi anak & $70,61 \%$ \\
\hline Hasil karya anak & $55,3 \%$ \\
\hline
\end{tabular}

Dari persentase hasil penelitian diatasmenunjukkan bahwa peran media cerita berupa foto rekreasi anak mampu mengembangkan kemampuan berbicara anak sebesar 70,61\%. Pada saat anak melakukan show and tell dengan media foto bertema rekreasi yang anak bawa dari rumah, anak mampu menjelaskan dan mengungkapkan perasaannya dan mampu menceritakan kembali pengalaman yang pernah anak lakukan. Media foto mampu mengembangkan kemampuan berbicara anak karena foto merupakan salah satu benda konkret. Dengan media foto anak mampu mengingat kembali pengalaman yang pernah anak lakukan dan mampu mengutarakan, menyampaikan dan menceritakan kembali. Media foto yang anak gunakan merupakan foto bertema rekreasi yang anak bawa dari rumah. Dengan begitu anak mampu terstimulus kemampuan berbicaranya dengan media foto. Dari penggunaan media foto ini juga dapat dihasilkan bahwa kemampuan berbicara anak juga dipengaruhi oleh pengalaman anak. Media foto mampu mengembangkan kemampuan berbicara anak lebih tinggi daripada hasil karya karena media foto merupakan gambar asli dari pengalaman yang pernah anak lakukan.

Berbeda dengan foto, peranan media gambar dari hasil karya anak hanya mampu mengembangkan kemampuan berbicara sebesar 55,3\%. Peran media gambar hasil karya anak tidak mampu tinggi dalam mengembangkan kemampuan berbicara karena berbagai hal.Pada penelitian ini, guru menggunakan media hasil karya anak untuk melakukan show and tell guna melihat kemampuan berbicara anak. Tahap pertama anak diminta menggambar tempat rekreasi yang pernah dikunjungi. Anak diberikan kebebasan dalam menggambar.Hal ini dikarenakan pengalaman rekreasi anak satu dengan yang lainnya berbeda-beda tempat. Tidak sedikit anak yang berfikir dahulu dan mengingat-ingat kembali pengalaman rekreasinya sebelum menggambar. 
Setelah anak selesai menggambar, guru mempersilahkan anak untuk menceritakan hasil karyanya bertema rekreasi di depan kelas secara bergiliran. Banyak anak yang terlihat masih sulit berbicara dan menceritakan hasil karyanya. Gambaran anak usia dini yang masih bersifat simbolis merupakan salah satu faktor penyebab peran hasil karya anak kurang maksimal dalam mengembangkan kemampuan berbicara. Sifat menggambar simbolis inilah yang membuat anak kurang mampu menyampaikan maksud dan perasaannya. Beberapa anak hanya menggambar sebuah kapal. Kapal yang digambarnya dimaksudkan anak pernah berekreasi ke pantai dan melihat kapal. Namun dengan sifat menggambar yang simbolis inilah justru membuat anak tidak mampu mengutarakan dan menceritakan apa maksud dan perasaannya lewat gambar yang dibuatnya. Dalam kegiatan show and tell dengan menggunakan gambar, anak hanya sebatas menceritakan gambarnya dan tidak menceritakan kembali pengalaman rekreasinya. Berbeda dengan penggunaan media foto, dimana anak mampu menceritakan kembali pengalam yang pernah anak lakukan terkait dengan foto tersebut. Pada penggunaan media gambar lebih rendah pengaruhnya terhadap kemampuan berbicara dapat disebabkan oleh keterbatasan objek yang digambar oleh anak. Anak kurang mampu berekspresi dalam menggambar sehingga berpengaruh terhadap kemampuannya menceritakan hasil karya gambarnya. Hal ini menunjukkan bahwa peran media foto lebih berpengaruh terhadap pengembangan kemampuan berbicara anak.

Mary R Jalongo menjelaskan bahwa konteks fisik yang salah satunya merupakan media merupakan faktor yang mempengaruhi kemampuan berbicara anak. Pengaruh media dalam penelitian yang dilakukan dengan metode show and tell ini sangatlah banyak. Terlihat ketika anak mulai bingung untuk menjelaskan serta menyampaikan maksudnya, berulangkali anak melihat dan memperhatikan media yang dibawanya. Dengan melihat gambar atau foto yang dibawanya anak menjadi terstimulasi dan terpacu untuk bicara serta mampu menjelaskan apa yang ingin dikatakannya. Dalam penelitian ini memperlihatkan bahwa media cerita sangat berperan dalam mengembangkan kemampuan berbicara anak kelompok A. Khususnya media foto yang merupakan benda konkret yang sangat berperan dan mampu lebih tinggi mengembangkan kemampuan berbicara anak disbanding dengan media gambar dari hasil karya anak.

Dengan peran media cerita berupa foto dan gambar hasil karya anak yang mampu mengembangkan kemampuan berbicara ini, maka pendidik diharapkan mampu meenggunakan media untuk mengembangkan kemampuan berbicara dengan lebih kreatif dan inovatif. Dan dengan pemberian keleluasaan kepada anak untuk berbicara, bercerita, mengungkapkan serta menjelaskan isi pikiran dan maksudnya akan membuat perkembangan kemampuan bicara anak menjadi lebih baik. Dengan berbagai tema yang digunakan di sekolah dan penggunaan media yang kreatif akan membuat anak lebih antusias dan termotivasi untuk berbicara dan mengungkapkan maksud.

\section{KESIMPULAN}

Berdasarkan hasil penelitian dan pembahasan, disimpulkan bahwa media cerita berupa foto dan gambar hasil karya anak berpengaruh pada pengembangan kemampuan berbicara anak. Hal ini dibuktikan dengan presentase dari hasil penelitian tentang kemampuan berbicara bahwa peran media foto mampu mengembangkan kemampuan berbicara sebesar 70,61\%. Selain media foto, gambar hasil karya anak juga berperan dalam pengembangan kemampuan berbicara anak meskipun tidak setinggi foto yakni sebesar $55,3 \%$. 
Dengan peran media yang penting terhadap pengembangan kemampuan berbicara ini, maka pendidik diharapkan mampu memberikan media cerita kepada anak untuk mengembangkan kemampuan berbicaranya secara kontinue.Selain itu sebagai seorang pendidik juga seharunya lebih kreatif dan inovatif dalam menerapkan metode serta merancang dan memberikan media pembelajaran kepada anak agar aspek kemampuannya terstimulasi.

\section{DAFTAR PUSTAKA}

2015. Anak hilang di mall? bekali anak dengan Pengetahuan Ini. Diakses pada tanggal 20 Agustus 2016 dari https://id.theasian parent.com.

Bygate Martin, 1987. Speaking, Oxford : Oxford University Press.

H.A.R Tilaar. (2013). Media pembelajaran aktif. Bandung: Nuansa Cendekia.

Hurlock, Elizabeth B. (1978). Perkembangan anak Jilid I. (Terjemahan Med. Meitasari Tjandrasa dan Muslichah Zarkasih). Jakarta: Erlangga.

Nana Syaodih Sukmadinata.(2010). Metode penelitian pendidikan. Bandung: PT. Remaja Rosdakarya.

Santrock, J.W. (2007). Perkembangan anak edisi Kesebelas Jilid 2. (Terjemahan Mila Rachmawati, S.Psi dan Anna Kuswanti). Jakarta: Erlangga

Sardjono.(2005). Terapi wicara. Jakarta: Depdiknas.
Slamet Suyanto. (2005). Dasar-dasar pendidikan anak usia dini. Yogyakarta: Hikayat Publishing.

Smaldino, Sharon E., Deborah L. Lowther \& James D. Russel. (2011). Instructional Technology \& Media For Learning. Penerjemah: Arfi Rahman. Jakarta: Kencana

Suharsimi Arikunto. (2006). Prosedur penelitian suatu pendekatan praktik. Jakarta: PT Rineka Cipta. 